\title{
Effects of Immigration in Europe
}

\author{
Winfred M. Mutheu ${ }^{1}$, David O. Ouma ${ }^{2}$, Njoki N. Njonjo ${ }^{3}$, Chemilil Kibet ${ }^{4}$, Mumtaz Musa ${ }^{5}$

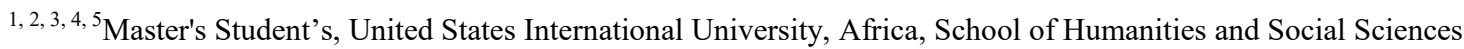 \\ P. O. Box 14365-00800, Nairobi, Kenya
}

\begin{abstract}
Immigration brings with it a host of diverse challenges to the host countries all across the world. In as much as some positive impacts of immigration abound, lately, immigration has been largely correlated with diverse negative issues. Among the positive effects of immigration is the availability of cheap labor for host countries which cuts down on labor costs and ultimately production costs. Furthermore, immigrants present a new market for produced goods and services. However, immigrants can also be a source of political instability in a country if the contemporary spate of immigrant related security concerns including terrorism are anything to go by. Furthermore, there is the real fear of immigrants growing exponentially in numbers and taking over the governance of their host nations. There is a broad based unanimity that the current observable immigration into Europe is evolving into a crisis. Various immigration issues bedevil Europe with an ever increasing influx of immigrants from war torn and unstable regions. In as much as some economic benefits are realized with this influx, Europe is increasingly facing new political, social and other economic challenges. A strain in resources and available amenities is now a reality as immigrants compete with locals for resources. Increased crime rates within nations in Europe are also a present day reality. Immigrants equally play an invaluable role on Greece' economy. Reeling from a recent economic debacle, immigrants have offered a much needed reprieve to Greece and have bolstered her economy. First, immigrants provide ready and cheap skilled labor for Greece and a ready market. Secondly, an influx of skilled immigrant workforce who secure employment contribute to Greece' tax revenue. Consequentially, this manuscript offers a succinct appraisal on the effects of immigration in Europe as well as the witnessed economic effects in Greece.
\end{abstract}

Keywords: Cheap Skilled Labor, Greece' Tax Revenue, Economy, Greece's Immigration, Europe

\section{Introduction}

Immigration involves the movement of people from their home country to settle in a host country where they are not natives. People immigrate for many reasons. Some of these reasons include economic or political reasons, family reunification, natural disasters, or the desire to change one's surroundings. Immigration can also represent an expansion of the supply of labor in the host country. Immigrants also move when the standard of living is not high enough in their countries or when wages are low coupled with a slow job market or a lack of educational opportunities (Geddes, 2015).

Immigration thus remains a hotly debated issue the world over hitherto. Proponents of immigration continually argue that the benefits brought about by immigration far outweigh any real or potential challenges. However, dynamics of immigration reveal that gains and challenges occur in equal measure as (Gur, 2015) documents.

Host countries are often faced with a variety of challenges due to immigration including population surges, support services, employment, and national security concerns. The current immigration crisis in Europe for instance, has 'coincidentally' coincided with an unprecedented upsurge in crime and terrorism levels in Europe for decades as (Gur, 2015) documents. Such worrying observations only serve to buttress the belief that the consequences of immigration far outweigh any potential benefits. Some of the challenges that come with immigration include stress being placed on resources such as hospitals or other amenities. In some European countries for instance, the police people ratio has dropped since the onset of the immigration crisis following the unrest in Middle East countries (Fetzer, 2016)

However, a cheap labor force and a ready market for produced goods is a noteworthy beneficial aspect that comes with immigration albeit critics argue that the purchasing power of immigrants is quite low to have any significant impact as (Kasnauskiene, 2015) document. Greece for instance, has particularly benefited from the immigrant crisis in Europe in some way, given that the country is just reeling from the after effects of an economic crisis as Gialis, Herodand Myridis (2014) documents. Regardless of any standpoint on this contentious issue, the impact of immigrants in Europe and Greece is undeniable.

\section{Overview of Impact of Immigration}

In 2006, the International Organization for Migration estimated the number of foreign migrants worldwide to be more than 200 million. Europe, North America, and Asia host the largest number of immigrants totaling 70 million, 45 million, and 25 million in 2005, respectively. 


\section{International Journal of Science and Research (IJSR) \\ ISSN (Online): 2319-7064}

Index Copernicus Value (2013): 6.14 | Impact Factor (2015): 6.391

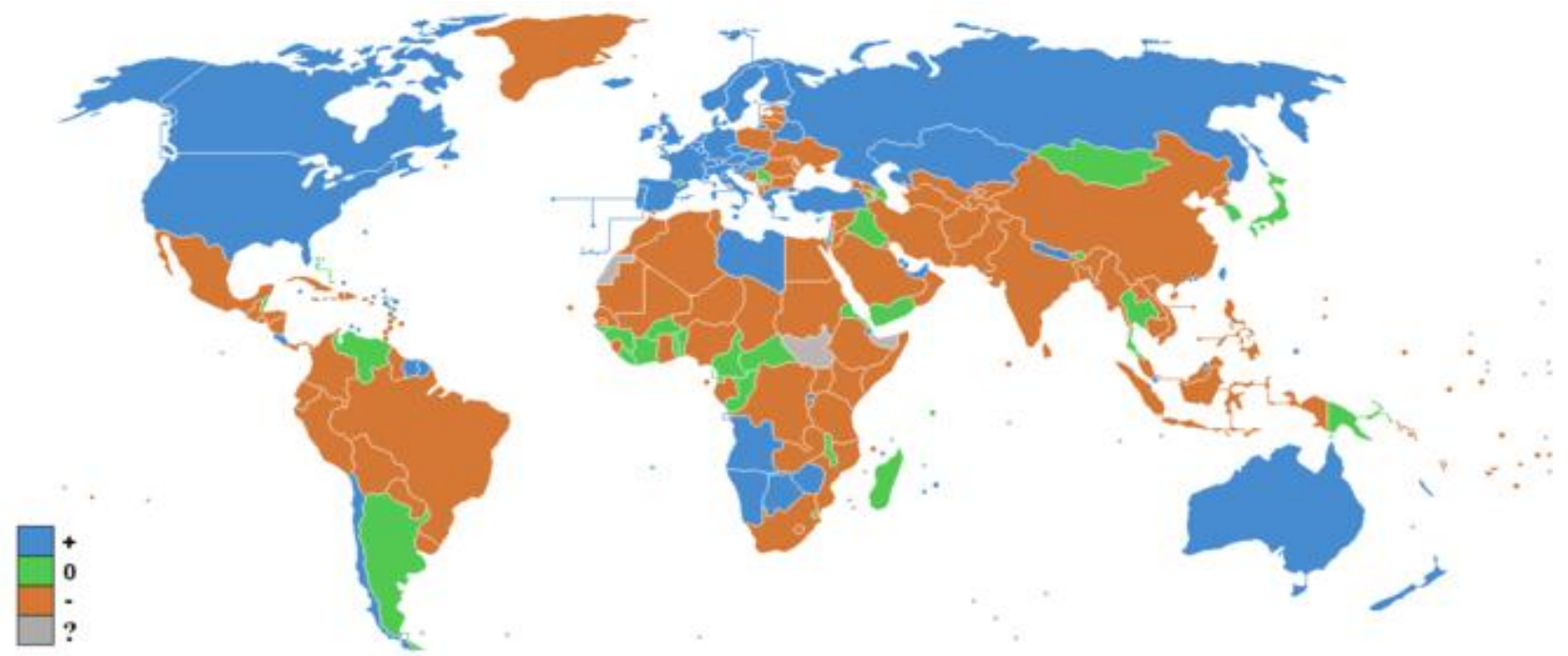

Figure 1: Immigration Rates

This map shows the migration rates worldwide in 2011. The blue countries experienced positive rates, orange indicates negative rates, green shows stable rates, and the gray shows where no data was available. Immigration involves individuals moving from their home country to live in a non-native country. In 2005, Europe, the United States, and Asia had the highest levels of immigration worldwide.

\subsection{Impacts of immigration on the Host Country}

A host country experiences both advantages and challenges as a result of immigration. At certain times throughout history, larger migrations have taken place which created huge population surges. The higher population numbers placed strain on the infrastructure and services within the host country. When immigrants move to a new country, they are faced with many unknowns, including finding employment and housing, as well as adjusting to new laws, cultural norms, and possibly a new language. It can be a challenge for a host country to assimilate immigrants into society and provide the necessary support. Immigration does cause an increase in the labor force. This can impact great quantities of them if the immigrants are generally the same type of worker (e.g. lowskilled) and immigrate in large enough numbers so as to significantly expand the supply of labor.

Immigration is still a heavily debated topic in many host countries. Some believe that immigration brings many advantages to a country both for the economy and society as a whole. Others believe that high immigration numbers threaten national identity, increase dependence on welfare, and threaten national security (through illegal immigration or terrorism). Another argument is that high immigration rates cheapen labor. Empirically, research has shown this may be partially true. The Brookings Institute found that from 1980 to 2007, immigration only caused a $2.3 \%$ depression in the wages of the host country. The Center for Immigration Studies found a $3.7 \%$ depression in wages during 1980 to 2000 .

\subsection{Impacts of immigration on the Home Country}

The home country also faces specific challenges in regards to immigration. In many cases, immigrants move to another country to provide positive changes for their future. Reasons to immigrate can include the standard of living not being high enough, the value of wages being too low, a slow job market, or a lack of educational opportunities. A home country must analyze immigration statistics to determine and address why citizens are moving to other countries. In the long-run, large amounts of immigration will weaken the home country by decreasing the population, the level of production, and economic spending. If a country is losing citizens due to economic reasons, the situation will not improve until economic changes are made.

At times, citizens of a country may leave because of noneconomic reasons such as religious persecution, ethnic cleansing, genocide, war, or to escape the government (for example, a dictatorship). In these cases, it is not uncommon for the citizens to return to the home country at some point once the threat is no longer present. While a citizen is living in another country, if they receive an education and create a solid life, their individual success can also be beneficial to the home country, if they use their acquired skills to make a difference. Many individuals do not forget their home country and continue to support family members financially through the income from the country they migrate to.

\section{Economic Effects of Immigration, Europe (Greece)}

The economic impact of migration is no exception. It can be helpful to look at migration's effects in three areas - the labor market, the public purse and economic growth.

Volume 5 Issue 8, August 2016 www.ijsr.net 


\section{International Journal of Science and Research (IJSR) \\ ISSN (Online): 2319-7064}

Index Copernicus Value (2013): 6.14 | Impact Factor (2015): 6.391

\subsection{Labor Markets}

- Migrants accounted for $70 \%$ in Europe over the past ten years.

- Migrants fill important niches both in fast-growing and declining sectors of the economy.

- Like the native-born, young migrants are better educated than those nearing retirement.

- Migrants contribute significantly to labor-market flexibility, notably in Europe.

\subsection{The Public Purse}

- Migrants contribute more in taxes and social contributions than they receive in benefits.

- Labor migrants have the most positive impact on the public purse.

- Employment is the single biggest determinant of migrants' net fiscal contribution.

\subsection{Economic Growth}

- Migration boosts the working-age population.

- Migrants arrive with skills and contribute to human capital development of receiving countries.

- Migrants also contribute to technological progress (OECD, 2014).

Over the last decades the above aspects of migration have been attested in the economic and social affairs of Greece. The genesis of this massive migrant inflows started with the collapse of socialist regimes in Central and Eastern Europe in the early 1990's, the return flows provoked by the severe economic crisis affecting Greece since 2008, and the outflows of Greek nationals sparked by the same recession (Cavounidis, 2013).

The impact of these inflows and outflows on the economic and social landscape of Greece is multi- faceted (Cavounidis, 2013):

- The abrupt change from a relatively homogeneous to a very diverse population of Greece in the decade subsequent to the collapse of socialist and communist countries in Central and Eastern Europe,

- Expansion of informal employment,

- The substitution of family labor in small family enterprises and the home by migrant wage-labor,

- The entry of Greece into the Euro zone in 2001, which according to many observers was facilitated by the migrant presence.

- Continuation of unauthorized inflows of migrants without their being incorporated into wage-work as were previous waves of migrants,

- Expansion of return migration,

- The new wave of emigration by Greeks.

The impact of the increase in immigration that took place between 2000 and 2007 is positive on the overall net income of natives. Moreover, as expected, it lowers the unemployment and raises the wage rate of skilled native workers. This occurs because unskilled immigration influx raises the marginal product of skilled labor; thus, it raises its wage and lowers its unemployment.

As regards the unemployment rate of unskilled labor, the entrance of unskilled immigrants lowers the expected employment cost, owing to the lower wages paid to immigrants, and encourages unskilled job entry. This leads to a lower unemployment rate. As for the wage of unskilled native workers, on the one hand, the higher availability of unskilled jobs strengthens their bargaining position and pushes their wage up, but, on the other, the fall in their marginal product, due to the relatively higher quantity of unskilled labor, causes their wage to fall (Palivos \& Chassamboulli, 2013).

In perfect - competitive markets, migration only affects the level of wages. The characteristics of migrants are those that determine which groups of native workers will observe a fall in wages. For example, if the majority of immigrants are employed in low skilled occupations, it is clear that the consequences of immigration will be harmful particularly to native unskilled workers. This can lead to the improvement in the position of other skilled workers (increase in demand for labor) employed in complementary sectors in the host country (Siokorelis, 2011).

Remittances are a crucial factor when considering the phenomenon of migration9. Specifically, they contribute to the increase of disposable income and consumption in the recipient country (Albania) and enhance the development process. Just the opposite effect is observed in the host country where the outflow of foreign exchange reduces demand putting pressure on markets for goods and money (Siokorelis, 2011).

In a nutshell:

Migrant workers make important contributions to the labor market in both high- and low-skilled occupations. Immigrants represented about a quarter of entries into the most strongly declining occupations in Europe (24\%). In Europe, these occupations include craft and related trades workers as well as machine operators and assemblers; in all these areas, immigrants are filling labor needs by taking up jobs regarded by domestic workers as unattractive or lacking career prospects (OECD, 2014).

\subsection{In Europe free movement migration helps address labor market imbalances}

In Europe, the scope of labor mobility greatly increased within the EU/EFTA zones following the EU enlargements of 2004 and 2007. This added to labor markets' adjustment capacity. Recent estimates suggest that as much as a quarter of the asymmetric labor market shock - that is occurring at different

Volume 5 Issue 8, August 2016 


\section{International Journal of Science and Research (IJSR) \\ ISSN (Online): 2319-7064}

Index Copernicus Value (2013): 6.14 | Impact Factor (2015): 6.391

times and with different intensities across countries - may have been absorbed by migration within a year (OECD, 2014).

\subsection{Migrants contribute more in taxes and social} contributions than they receive in individual benefits

Immigrants are neither a burden to the public purse nor are they a panacea for addressing fiscal challenges. In most countries, except in those with a large share of older migrants, migrants contribute more in taxes and social contributions than they receive in individual benefits. This means that they contribute to the financing of public infrastructure, although admittedly to a lesser extent than the native-born (OECD, 2014).

\subsection{Migration contributes to spur innovation and economic growth}

International migration has both direct and indirect effects on economic growth. There is little doubt that where migration expands the workforce, aggregate GDP can be expected to grow. However, the situation is less clear when it comes to per capita GDP growth (OECD, 2014).

\section{Conclusion}

In conclusion, immigrants offer interesting dynamics on their impact on jurisdictions. On one hand, the plausible economic gains are desirable and on the other hand, numerous issues abound regarding immigration. Top among the discussed issues is a weakened host economy as governments overspend on immigrants. Furthermore, little correlation has been documented to exist between the host country's GDP and the volume of remittances made. In the current world also, security and terrorism is a valid global concern. The link between immigration and these vices is thus worrying. It is thus imperative to critically consider foreign and international policies governing immigration given the raised pertinent concerns. Additionally, the economic gains brought about by immigrants must be weighed alongside other metrics such as social and political gains in order for mutually benefiting decisions to be made. Therefore, in as much as immigration is largely an unplanned population issue, managing it is a deliberate choice since its effects reverberates across other social political, economic and cultural aspects.

\section{References}

[1] Cavounidis, J. (2013). Migration and the Economic and Social Landscape of Greece. South-Eastern Europe Journal of Economics, 1, 59-78.

[2] Fetzer, J.S. (2016). Open Borders and International Migration Policy: The Effects of Unrestricted Immigration in the United States, France, and Ireland. New York:St Martin's Press LLC.

[3] Geddes, A. (2015). Framing the Causes and Consequences of Immigration: Evidence from the European Union. Council for European Studies Conference. South
Yorkshire: University of Sheffield. Retrieved July 28, 2016, from:https://ces.confex.com/ces/2015/webprogram/Paper9 985.html.

[4] Gur, S. (2015). The Effects of Religion on the Immigration Process in the USA: An Experiment. International Relations and Diplomacy,3(1), 28-40.

[5] Kasnauskiene, L. C. (2015). Too high or just right? Costbenefit approach to emigration question. Engineering Economics,61(1), 7-12.

[6] OECD. (2014). Migration Policy Debates. Retrieved July 28, 2016, from:https://www.oecd.org/migration.

[7] Siokorelis, V. K. (2011). Economic Effects of Migration from Albania to Greece: An Empirical Approach. JIMS,5(1), 117 - 128.

[8] Palivos, T.\&Chassamboulli, A. (2013). The Impact of Immigrationon the Employment and Wages of Native Wokers. University of Cyprus, Economic Research Department. Venizelos: Bank of Greece Printing Works.

Volume 5 Issue 8, August 2016

www.ijsr.net

Licensed Under Creative Commons Attribution CC BY 